the Greenland ice sheet will melt away in a few centuries once we pass the 'tipping point'. I also missed a more thorough discussion of what would happen to sea levels and all of Earth's ice, known collectively as the cryosphere, if there were no anthropogenic influences on climate.

The slow, ongoing processes in ice sheets may be poorly understood, but they are likely to have implications for the future. For example, it is clear that the West Antarctic Ice Sheet is currently losing mass, but there is abundant evidence that the shrinkage has been happening for the past 15,000 years, mainly in response to rising sea levels initiated by deglaciation in the Northern Hemisphere. Thus, limiting greenhouse warming may not lead to the desired stabilization of the ice sheet. We must then ask whether we want the cryosphere to remain as it is today, or for it to follow its own course with a minimum of anthropogenic influence. To answer this question we need to know the consequences. Fortunately, large amounts of ice-sheet data are now becoming available, particularly from the many different sensors on various space satellites. With clever modelling, in ten years' time we should be able to quantify the effect of slow ongoing processes on the future of the ice sheets.
A World Without Ice is kaleidoscopic: a collection of anecdotes, scientific lectures, travel reports, political statements and repeated arguments. In lacking a strong narrative it doesn't match my personal favourite in climate science, Ice Ages: Solving the Mystery (Enslow, 1979) by John Imbrie and Katherine Palmer Imbrie. But Pollack's entertaining book is worth reading, even if it does not offer the full story.

Johannes Oerlemans is professor of meteorology at the Institute for Marine and Atmospheric

Research, Utrecht University, Princetonplein 5, 3584 CC Utrecht, the Netherlands.

e-mail: j.oerlemans@uu.nl

\title{
Gail Wight, artist of science
}

\author{
Restless Dust \\ by Gail Wight \\ Imprint of the San Francisco Center for the \\ Book: 2009.36 pp. $\$ 280$
}

The artist Gail Wight has examined X-rays with neuroscientists, pored over skeletal remains alongside archaeologists and thawed insects with animal behaviourists.

Wight, an associate professor in the Department of Art and Art History at Stanford University in California, likens her role in these short-term apprenticeships to that of a "lurker". The term is characteristic of her approach, in that it simultaneously diminishes her stature and emphasizes the tension inherent in the relationship. Some of these professional associations are internship-like shadowing sessions; others develop into something akin to collaboration. Each has led Wight to produce unique works of art that, over 20 years or so, have spanned media from photography and sculpture to film and performance art.

Among Wight's videos are colourful grids of the slime mould Physarum polycephalum, its growth visible using accelerated footage. Her Ground Plane large-format prints, depicting fossilized materials collected by Elizabeth Hadly's lab at Stanford University, include what might be termed 'mandible mandalas'. The massive, snowflake-like patterns are hand-constructed from photos of tiny fragments of animal bones, some of which are more than 10,000 years old.

Wight's sculptures include large-scale Plexiglas musical instruments that are 'played' by the mice captured inside them. If the captive mice bring to mind those that are probed and dissected in laboratories, the parallel isn't misguided. "I'm really interested in a critique of science, and one that scientists would appreciate," says Wight. "Scientists are the best [placed] to understand what's wrong with their field. I've been pretty delightfully surprised to find that they really love the critique aspect."

Another piece in which she aligns herself with the specimens of science, rather than with scientists, is one of her early performance works from 1992, School of Evolution. Its form took that of a day-long seminar, during which her audience was a fountain full of fish; she encouraged them to get on with evolution and thus escape their aquatic confines.

Humour is never far from Wight's artistic toolbox; nor, of late, has been the topic of evolution, through another collaboration - not with a living scientist but the ghost of one. For Restless Dust, an artist's book she completed this autumn during a residency in California at the San Francisco Center for the Book, Wight imagined taking Charles Darwin on a tour of the San Francisco Bay area to record his impressions. A visit to a genetics lab makes him think about inbreeding - something that Darwin, who married his cousin, feared may have precipitated the premature deaths of three of their children.

Wight's book marks the occasion of the 150th anniversary of the publication of Darwin's On the Origin of Species, and the result is a leather-bound, letterpress-printed journal not unlike the one in which Darwin made the notes that eventually became The Voyage of the Beagle. These journals, which Wight produced in an edition of 50, are housed in small pine boxes - "little coffins", she jokes - that also contain life-sized, rice-paper models of a pair of mockingbirds, modelled on Darwin's own research material. The body cavity of each bird pulses with the dim light of a small, batterypowered bulb. The ghost may be Darwin's, but his specimens are memorialized too.

One of Wight's many scientist-collaborators is the animal behaviourist Lucia Jacobs at the University of California, Berkeley, who praises

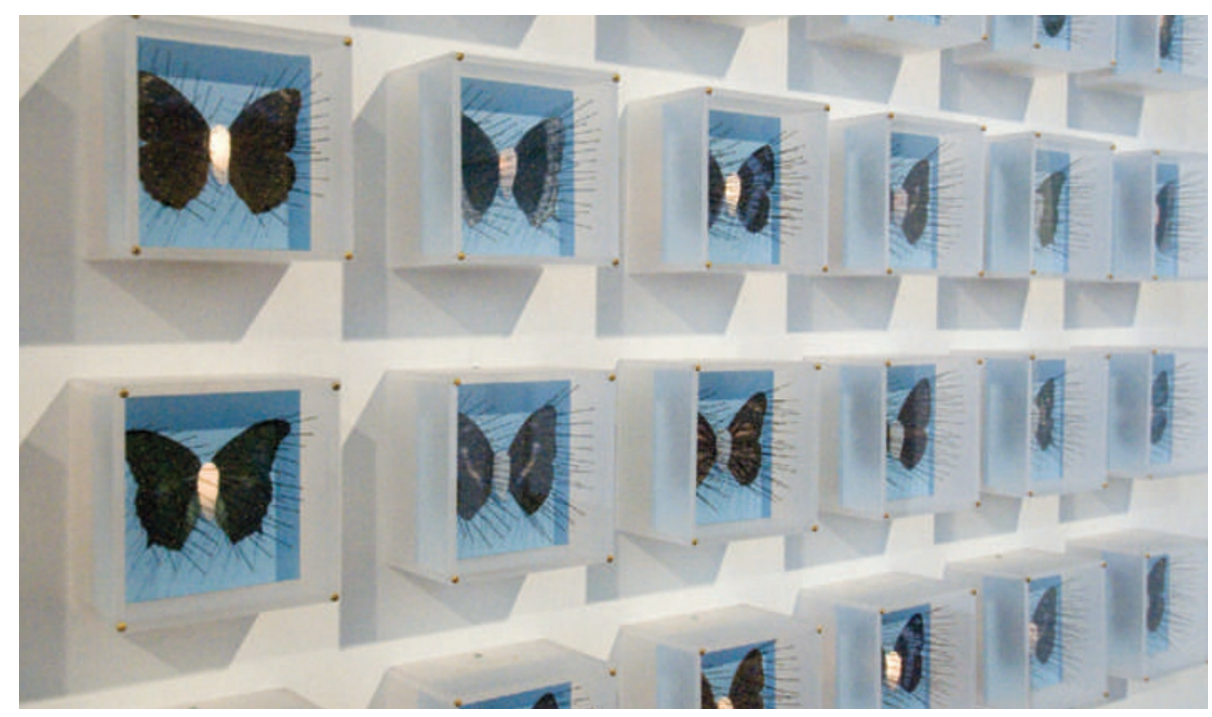

Gail Wight explores the habits and history of scientific practice in this installation of pinned butterflies. 
the depth of Wight's engagement: “There's a lot of 'pretty' art about science, and there's a lot of art that involves technology," says Jacobs, "but that's not the same thing. Science is a way of pursuing truth, and Gail really loves that about science - but she's also kind of calling us on it, and in spectacular ways."

Jacobs likens Wight's research to playwright Tom Stoppard's use of maths in Arcadia, and mentions several artists-turned-scientists, such as Santiago Ramón y Cajal, whose efforts in founding the field of neuroscience succeeded his early career as a painter. "You could say she is a scientist about science," remarks Jacobs. "Her subject is science, and she's experimenting with it, using art, to understand the truth of it." Wight, however, would never apply the term scientist to herself. "Science is not my forte, it's not my world," she says. "But I live in the world largely constructed by science, so I want to understand it better."

She is an 'artist of science' in the same way that there are historians and sociologists of science. Wight explores the habits and history of science by using its materials as her materials, and producing art that serves both as work open to interpretation and as a pointed appraisal of scientific analysis. Consider her piece J'ai des papillons noirs tous les jours (2006), a series of colourful, handmade butterflies, each affixed to the back of its own narrow box by 100 pins (pictured) - the overkill begs the question: how many pins is too many? As with the mockingbirds in Restless Dust, the butterflies' abdomens glow.

For all Wight's concerns about scientific practice, she has a firm sense of where the art ends and the science begins. Ultimately, she reserves her strongest critique not for scientists, but for her fellow artists, saying: "I have a lot of problems with the contemporary idea that an artist can enter into the world of science and practise science on living creatures without any of the background that should come with that."

Marc Weidenbaum is a writer based in

San Francisco, California.

e-mail:marc@disquiet.com

See go.nature.com/aedPm2 for more on Gail Wight's Restless Dust.
Chinese craftsmen in $50 \mathrm{BC}$, who mashed plant fibres such as hemp and flax with water, shaping the pulp into paper using a wooden mould. One such mould, with a screen made of woven reeds, is on display. The Chinese kept their paper-making technique a secret for centuries, but it slowly wound its way westwards. The Diamond Sutra, an ancient Buddhist text printed in $868 \mathrm{AD}$, is the oldest known dated example of a paper book and was found in a cave in Dunhuang, an oasis town that formed an interchange between China and western Asia. The first paper Koran was copied in Persia in $971 \mathrm{AD}$, and in 1150 Arabs set up the first paper mill in Al-Andalus, the Islamic territories in southern Spain.

Innovations travelled in the other direction, too. Glass-blowing was developed in the Middle East in around $100 \mathrm{BC}$, and then progressed eastwards: one beautiful, long-necked cloudy-white bottle from western Asia dating to 800-1000 AD is imprinted with pairs of graceful, curvedhorned ibex. Irrigation techniques also spread along the Silk Road: artificial underground rivers called karezes, which rely on gravity to carry mountain water to distant desert fields, were first used in Persia more than 2,500 years ago and still move nearly 300 million cubic metres of water in the Turpan Basin each year.

A mock market displays luxury goods offered by traders in Turpan: items such as leopard, tiger and ermine fur; red coral and green jade; a profusion of fruit including figs, peaches, pistachios and melons - the latter transported in lead containers packed with snow and medicines such as rhino horn, rhubarb, ginseng and bezoars, the brown pellets of undigested food extracted from the stomachs of goats and cows, purported to cure a range of ills and rid you of "perverse goblins", according to one Chinese doctor.

A final video quiz reminds us that the globalization of trade through the exhibition: Xian, the ancient capital of China, from which camel caravans set out loaded with silk for trade with the West; Turpan, an oasis city on the edge of the Taklimakan Desert in northwest China; Samarkand, a merchant city now in present-day Uzbekistan; and Baghdad, once a meeting place for scholars and known as the City of Peace. On the way, visitors grasp the great cultural and technological developments that flowed along the route: music, religion, language, numerals, medicines and innovations such as paper-making.

A two-metre-long, table-top interactive map charts these advances. Paper was invented by 